\title{
Compensation and Discipline on Performance Through Employee Motivation in the Secretariat
}

\author{
Heriani $^{1}$, Syamsul Alam ${ }^{\varpi_{2}}$ \\ 1, Soppeng Regency DPRD Secretariat \\ 2,Sekolah Tinggi Ilmu Ekonomi (STIE) Amkop Makassar \\ DOI : https://doi.org/10.37531/ecotal.v1i1.3
}

\begin{abstract}
The research location is at the DPRD Secretariat of Soppeng Regency. The sample in this study used the census method where the entire population was sampled in the study as many as 103 employees. In conducting statistical tests using path analysis. The results showed that compensation had a positive and significant effect on employee motivation. Discipline has a positive and significant effect on employee motivation. Compensation has a positive and significant effect on performance. Discipline has a positive and significant effect on performance. Employee work motivation has a positive and significant effect on performance. Compensation has a positive and significant effect on performance through employee motivation. Discipline has a positive and significant effect on performance through employee work motivation at the Soppeng Regency DPRD Secretariat.
\end{abstract}

\section{Keywords:}

Compensation, Discipline, Performance and Work Motivation of Employees

\begin{abstract}
Abstrak : Lokasi penelitian berada di Sekretariat DPRD Kabupaten Soppeng. Sampel dalam penelitian ini menggunakan metode sensus dimana seluruh populasi dijadikan sampel dalam penelitian sebanyak 103 karyawan. Dalam melakukan pengujian statistik menggunakan analisis jalur. Hasil penelitian menunjukkan bahwa kompensasi berpengaruh positif dan signifikan terhadap motivasi kerja pegawai. Disiplin berpengaruh positif dan signifikan terhadap motivasi kerja pegawai. Kompensasi berpengaruh positif dan signifikan terhadap kinerja. Disiplin berpengaruh positif dan signifikan terhadap kinerja. Motivasi kerja karyawan berpengaruh positif dan signifikan terhadap kinerja. Kompensasi berpengaruh positif dan signifikan terhadap kinerja melalui motivasi kerja pegawai. Disiplin berpengaruh positif dan signifikan terhadap kinerja melalui motivasi kerja pegawai pada Sekretariat DPRD Kabupaten Soppeng.
\end{abstract}

Kata Kunci : Kompensasi, Disiplin, Kinerja dan Motivasi Kerja Karyawan

$\triangle$ Corresponding Author :

E-mail address: syamsul_alam@stienobel-indonesia.ac.id (Kota Makassar, Sulawesi Selatan)

“Received 06 December 2019, Accepted 02 January 2020, Published 18 January 2020" 


\section{Introduction}

Human resource management becomes a very important element of the management function. If human resources are not managed properly, organizational performance will decline faster than other resources. Human resources have a greater impact on achieving organizational goals. Therefore, in today's global era the activities of managing human resources effectively will further enhance organizational performance. And whoever manages the organization will process various resources to achieve the goals of the organization. Performance is not an individual characteristic, such as talent, or ability but is an embodiment of the talent or ability itself.

Performance is an embodiment of ability in the form of real work. Performance is the result of work achieved by employees in developing tasks and jobs that come from the organization. Discipline is compliance or adherence to certain and consistent provisions, both in the form of rules and regulations that have been determined to carry out organizational standards. In addition to work motivation there are other things that are also important to improve employee performance, namely with compensation. If the compensation policy is appropriate and in line with employee expectations, both in terms of fairness and eligibility, employees will feel satisfied and increasingly motivated to carry out various activities related to achieving organizational goals. Conversely, if the compensation received is deemed unfair and its eligibility is not met, it will cause employees to complain, thus impacting on work motivation which in turn will cause employee performance to decline.

This is very relevant to the results of the study of (NN Mariana, 2018), the research title The Effect of Competence, Compensation and Motivation on Employee Performance in the Public Works and Spatial Planning Office in Bantaeng Regency. Quantitative descriptive data analysis survey research methods using multiple linear regression analysis methods, where the results of the study show that 1) Competence has a positive and significant effect on employee performance in the Public Works and Spatial Planning department in Bantaeng district, 2) Compensation has a positive and significant effect on performance Employees in the Public Works and Spatial Planning Office in Bantaeng Regency, 3) Motivation has a positive and significant effect on the Performance of Employees in the Public Works and Spatial Planning Office in Bantaeng Regency and the results of the (Sari, 2016), with the title research Effect of 
Heriani1 $^{1}$, Syamsul Alam ${ }^{\otimes_{2}}$

Compensation and Discipline on Performance Through Employee Motivation in the Secretariat

DOI : https://doi.org/10.37531/ecotal.v1i1.3

Work Discipline and Leadership on Employee Performance in the District Office of Donri-Donri, Soppeng Regency. The results of his research show that 1) Work discipline has a positive and significant effect on employee performance at the Donri-Donri District Office in Soppeng Regency, 2) Leadership has a positive and significant effect on employee performance in the Donri-Donri District Office, Soppeng Regency, 3) Work Discipline and Leadership have positive and significant effect on employee performance in the Donri-Donri District Office, Soppeng Regency.

The phenomenon that occurs employees in the Soppeng Regency DPRD Secretariat is not as expected, for example employees in carrying out their duties and functions have not been able to carry out in accordance with set operational standards and sometimes employees work unproductive during office hours, as well as in terms of iscipline most employees have not complied and obeyed the rules that apply especially in terms of attendance during office hours, apples and have not been able to see that settlement work is a system.

\section{Literature Review}

\subsection{Compensation}

The establishment of effective compensation systems is an important part of human resource management because it helps attract and retain talented workers. In addition the company's compensation system has an impact on strategic performance. The reward system can include salary, income, retirement, vacation money, promotion to a higher position (in the form of higher salaries and profits). Also in the form of work safety insurance, transfer horizontally to get a more challenging position or to the main position for growth and further development, as well as various forms of service. Compensation is an integral part of human resource management which helps in motivating the employees and improving organizational effectiveness (B.C.M. Patnaik \& Prabir Chandra Padhi, 2012). Compensation is a key element of the employment relationship and, in addition to being the single greatest operating cost for many organizations, it has been advocated by some recently as a tool for enhancing organizational performance and sustained competitiveness (Trevor J, 2008). Compensation issues as a human resource function have a significant effect on employees' satisfaction, both economically and psychologically, in other words compensation systems influence both job satisfaction and employee motivation (Dalia Mohammad Soliman, 2009). 
Heriani1 $^{1}$, Syamsul Alam ${ }^{\otimes_{2}}$

Compensation and Discipline on Performance Through Employee Motivation in the Secretariat

DOI : https://doi.org/10.37531/ecotal.v1i1.3

\subsection{Discipline}

Employee discipline is a person's behavior in accordance with regulations, existing work procedures or discipline is an attitude, behavior and actions that are in accordance with the regulations of the organization both written and unwritten, discipline can be interpreted when employees always come and go home on time, do all his work well, comply with all company regulations and applicable social norms. Discipline can be defined when employees come and leave promptly the time, doing all the good work, comply with all company regulations and social norms prevailing (Esther Patricia Paoki, David P. E. Saerang and Sifrid S. Pangemanan, 2017). The first step in developing a disciplined approach to team management is to think about teams as discrete units of performance and not just as positive sets of values (Jon R. Katzenbach and Douglas K. Smith, 1993). The great philosopher, Aristotle said, "A nation is not built by mountains and trees, for withstanding it is built by character of its citizens" (Diksha Kasyhap, https://www.yourarticlelibrary.com/essay/discipline/essay-on-discipline-definition-conceptcomponents-and-principles/63727).

\subsection{Work motivation}

Motivation is the strength that is in a person, which encourages behavior to take action. The amount of power incentives in a person to do a task or achieve goals shows the level of motivation. And the desire found in an individual individual who stimulates it to take actions. Work motivation and job satisfaction of employees are essential for every business, as first and foremost, they affect the efficiency of work and related activities (Tiiu Kamdron, 2016). Work motivation is a process that directs and sustains the performance (Amir Sohail, Robina Safdar, Salma Saleem, Samara Ansar \& M. Azeem, 2014). Motivation is the desire that underlies each individual either from his own desires or encouragement from outside parties for the reason that each individual does something (Moch. Geri William, 2020). Work motivation is an important human resource management functions to join and stay talented workers, perform better and do extra for an organization, and one of the most important parts to focus on in order to gain organization success and competitive advantage (Adi Indrayanto, Sigit W.D. Nugroho and Titi Nurfitri, 2017).

\subsection{Performance}

Performance is the result achieved by a person or group of people who do work with certain criteria and evaluated by certain parties as well. If related to the work process, it can be interpreted as a condition that shows the ability of an employee to carry out their duties in the 
Heriani $^{1}$, Syamsul Alam ${ }^{\bigotimes_{2}}$

Compensation and Discipline on Performance Through Employee Motivation in the Secretariat

DOI : $\underline{\text { https://doi.org/10.37531/ecotal.v1i1.3 }}$

office or place of work. According to (Rivai. Sagala, 2003: 548) argued that: Performance is a function of motivation and ability to complete one's tasks or work duly have a certain degree of willingness and level of ability. Performance is the goal achievement of an organization rather than of individuals, with the minimum resources consumed to reach the goal (Ata Ghalem, Chafik Okar, Razane Chroqui and Semma El Alami, 2016). The overall function of performance appraisal is to provide an accurate measure of an individual's performance (Nasser Salim Alghanabousi, Muhammad Faizal A. Ghani, Faisol Elham, 2013).

\section{Method, Data, and Analysis}

\subsection{Research Design}

This research approach is a quantitative approach. Quantitative research approaches are methods for testing certain theories by examining the relationships between variables.

Figure 1. Soppeng Regency DPRD Regional Secretariat organizational structure

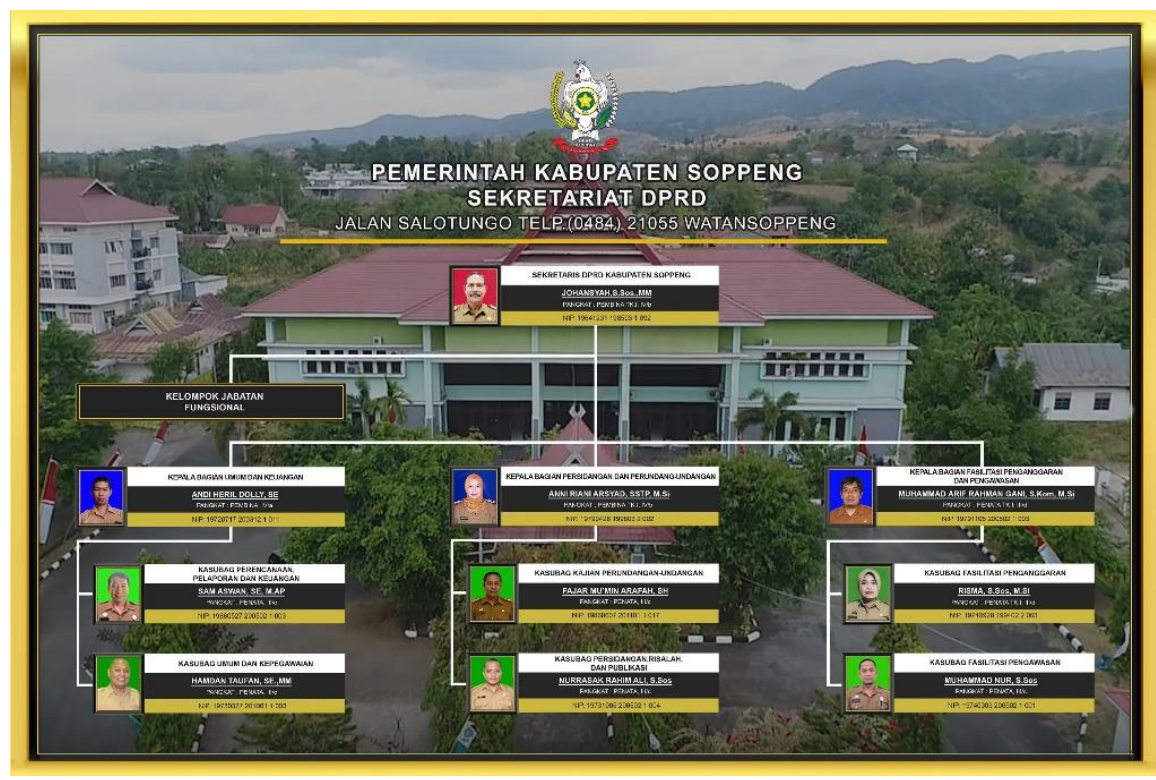

Source : Staff Office Soppeng Regency DPRD Regional Secretariat

\subsection{Sample Design}

The sample in this study were all employees in the Regional Secretariat of the Soppeng Regency DPRD, amounting to 103 people. 


\section{Result and Discussion}

\subsection{Path Analysis Model}

In statistics, path analysis or better known as Path Analysis is used to determine the direct dependence relationship between a set of variables. Path analysis is a model similar to multiple regression analysis model, factor analysis, canonical correlation analysis, discriminant analysis and other more general multivariate group analyzes such as anova, manova, anacova analysis. In terms of causality, Path Analysis can be viewed as an analysis similar to regression analysis. Both of them analyzed the causality model. The difference lies in the complexity of the model. The regression analysis model analyzes the dependent variable more as the impact of the independent variable. The dependent variable has no impact on other variables. When the researcher is faced with a model where the dependent variable causes another dependent variable, path analysis is more suitable. In other terms, path analysis can also be seen as SEM (Structural Equation Modeling) where path analysis is SEM which has only one indicator, or structural model of SEM analysis. The difference is that path analysis only analyzes construct variables, whereas in SEM all variables, both indicator variables and construct variables, are analyzed together in one model.

Path Analysis Model (Path Analysis) According (Kerlinger, 2006) explains that path analysis is an applied form of multi-regression analysis. Path diagrams are used to help conceptualize problems or test complex hypotheses. According to (Ghozali, 2011) explains that path analysis is a further development of multiple linear and bivariate regression analysis. Path Analysis examines the regression equation that involves several exogenous and endogenous variables at once to enable testing of mediating/intervening variables or intermediate variables. Besides that path analysis can measure direct and indirect relationships between variables in the model.

To test the hypothesis in research using path analysis. This is because the researcher wants to see the direct and indirect effect between compensation and discipline on employee performance mediated by intervening variables namely work motivation. In the path analysis the value used is the value located in Beta and if the indirect effect is greater than the direct effect the result is significant (Sahid Rahardjo, 2014).

Sobel test to test the strength of the indirect effect of the independent variable $(X)$ to the dependent variable (Y2) through the intervening variable (Y1). By calculating the indirect effect of X to Y2 through Y1 by multiplying paths X - Y1 (a) with paths Y1 - Y2 (b) or ab. So the 
coefficient $a b=\left(c-c\right.$ ') where $c$ is the effect of $X$ on Y2 without connecting $Y 1$, while $c^{\prime}$ is the coefficient of the effect of X on Y2 after connecting Y1. Ghozali (2011) argues that hypothesis testing can be done with procedures developed by Sobel (Sobel Test). The Sobel test formula is as follows:

Sat $=\sqrt{ }\left(\mathrm{b}^{\wedge} 2 \mathrm{Sa}^{\wedge} 2 \mathrm{a}^{\wedge} 2 \mathrm{Sb}^{\wedge} 2 \mathrm{Sa}^{\wedge} 2 \mathrm{Sb}^{\wedge} 2\right)$

With Remarks:

Sat: The magnitude of the standard error is an indirect effect

a: Independent variable path $(\mathrm{X})$ with intervening variable (Y1)

b: Path intervening variable (Y1) to the dependent variable (Y2)

sa: Standard error coefficient a

sb: Standard error coefficient b

To test the significance of the indirect effect, we need to calculate the value of $t$ of the coefficient using the following formula:

$\mathrm{t}=\mathrm{ab} / \mathrm{sab}$

The value of $t$ arithmetic is compared with the value of $t$ table, if the value of $t$ arithmetic $>$ value of $t$ table then it can be concluded that there is a mediating effect. The assumption of the sobel test requires a large number of samples, if the number of samples is small, the Sobel Test is less conservative, (Ghozali, 2011).

For more details, it can be described the path analysis model in this study. 
Heriani $^{1}$, Syamsul Alam ${ }^{\otimes_{2}}$

Compensation and Discipline on Performance Through Employee Motivation in the Secretariat DOI : $\underline{\text { https://doi.org/10.37531/ecotal.v1i1.3 }}$

Figure 1. Path analysis model

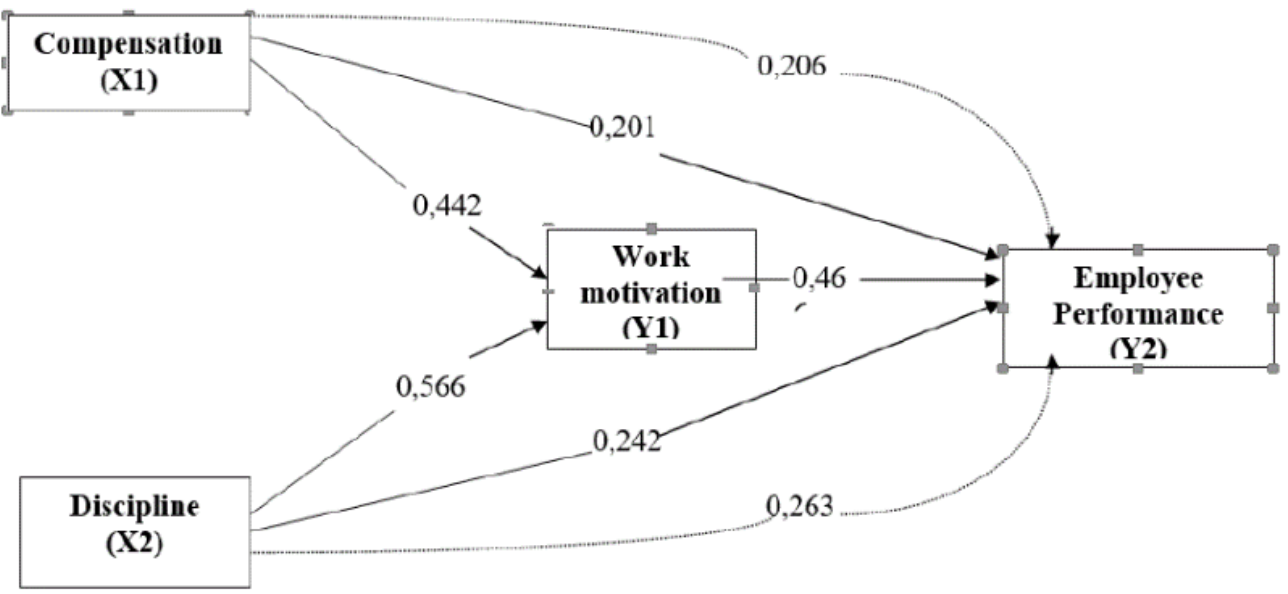

From the path analysis model, the path analysis equation formed is as follows:

$\mathrm{Y} 1$

Y1

Y2

Y2

$\mathrm{Y} 2=\mathrm{f}(\mathrm{X} 1, \mathrm{X} 2)$

$=\alpha 0 \alpha 1 \mathrm{X} 1 \alpha 2 \mathrm{X} 2 \mathrm{e} 1$

$=\mathrm{f}(\mathrm{X} 1, \mathrm{X} 2, \mathrm{Y} 1)$

$=\beta 0 \beta 1 \mathrm{X} 1 \beta 2 \mathrm{X} 2 \beta 3 \mathrm{Y} 1 \mathrm{e} 2$

$=\beta 0 \beta 1 \mathrm{X} 1 \beta 2 \mathrm{X} 2 \beta 3 \mathrm{Y} 1(\alpha 0 \alpha 1 \mathrm{X} 1 \alpha 2 \mathrm{X} 2 \mathrm{e} 1)$ e2

Where :

Y1

Y2

$\alpha 0 ; \beta 0$

$\mathrm{X} 1$

$\mathrm{X} 2$

$\alpha 1, \alpha 2, \beta 1, \beta 2, \beta 3$

e1, e2 = Work Motivation 
$=$ Performance

$=$ Constant

$=$ Compensation

$=$ Discipline

$=$ Regression line coefficient

= Error or confounding variable

\subsection{Effect of Compensation on Work Motivation}

From the results of testing the first hypothesis shows that compensation has a positive and significant effect on employee work motivation. This is indicated by the value of tcount 4.161>t table 1.984 with a significance value of 0.000 . Soppeng will increase, and vice versa if the compensation given is not feasible, then employee motivation will also be lower.

\subsection{Effect of Discipline on Work Motivation}

From the results of the second hypothesis testing shows that discipline has a positive and significant effect on employee work motivation. This is indicated by the value of tcount $6.876>t$ table 1.984 with a significance value of 0.000 . This shows that the higher the level of employee discipline, the employee work motivation at the Soppeng District Parliament Secretariat will increase, and vice versa if the employee discipline is low, then the employee's work motivation will also be lower.

\subsection{Effect of Compensation on Performance}

From the results of testing the third hypothesis shows that compensation has a positive and significant effect on employee performance, this is indicated by the value of tcount 1,991>ttable 1,984 with a significance value of 0,009 . increase, and vice versa if the compensation provided is not feasible, then employee performance will also be lower.

\subsection{Effect of Discipline on Performance}

From the results of the fourth hypothesis testing shows that discipline has a positive and significant effect on employee performance. This is indicated by the value of tcount1.985> ttable 1.984 with a significance value of 0.007. increasing, and vice versa if the employee discipline is low, then the employee's performance will also be lower. Descriptive analysis results that the 
Heriani $^{1}$, Syamsul Alam ${ }^{\bigotimes_{2}}$

Compensation and Discipline on Performance Through Employee Motivation in the Secretariat

DOI : https://doi.org/10.37531/ecotal.v1i1.3

most influential indicator on employee performance variables is the indicator of work quality where the indicator is the mean value of 4.47. then the initiative indicator the mean value is 4.40 , then the independence indicator the mean value is 4.38 , the quantity indicator is the mean value 4.36 , the cooperation indicator the mean value is 4.30 . And the indicator with the lowest influence is the adaptability indicator with a mean value of 4.29 .

\subsection{Effect of Work Motivation on Performance}

From the results of testing the fifth hypothesis shows that work motivation has a positive and significant effect on employee performance, this is indicated by the value of tcount $3.482>$ ttable 1.984 with a significance value of 0.001 . will increase, and vice versa if low employee motivation, then employee performance will also be lower. The results of respondents 'answers using descriptive analysis showed that the indicator (Y1.1) achievement of the majority of respondents' answers was agreed with a value of $64.1 \%$, the mean value of 4.20 and included in the very high category (between 4.01 - 5, 00). In indicator (Y1.2) affiliation, the majority of respondents' answers are very agree with a value of $64.1 \%$, the mean value of 4.24 and included in the very high category (between 4.01 - 5.00). In the indicator (Y1.3) Competence of the majority of respondents' answers is agreed with a value of $52.4 \%$, the mean value of 4.40 and in the very high category (between 4.01 - 5.00). In the indicator (Y1.4) the majority of respondents' answers are in agreement with a value of $59.2 \%$, the mean value of 4.37 and in the very high category (between $4.01-5.00$ ).

\subsection{Effect of Compensation on Employee Performance Through Work Motivation}

From the results of the sixth hypothesis testing shows that compensation has a positive and significant effect on performance through employee work motivation, this is indicated by the magnitude of tcount 2.0593> t table 1.984. This shows that the effect of compensation on employee performance through work motivation is a positive and significant effect, where the more appropriate compensation given, the employee's work motivation will also increase, so that the performance of employees in the Secretariat of the Soppeng Regency DPRD will also increase. 


\subsection{Effect of Discipline on Employee Performance Through Work Motivation}

From the results of testing the seventh hypothesis shows that discipline has a positive and significant effect on performance through employee work motivation, this is indicated by the value of tcount 2.00312> t table 1.984. This shows that the influence of discipline on employee performance through work motivation is a positive and significant effect, where if the level of discipline is high then employee work motivation will also increase, so that employee performance at the Soppeng Regency DPRD Secretariat will also increase.

\section{Conclusion}

a) If the granting of employee compensation is proper it will increase the work motivation of employees in the Secretariat of the Soppeng Regency DPRD, and conversely it is not appropriate compensation and low work discipline, the employee's work motivation will also be low.

b) If the high level of discipline will increase employee motivation and vice versa the lower the level of discipline, the employee's work motivation will also be low.

c) If the compensation given to employees is appropriate and as expected, the more the performance increases and vice versa the more improper the compensation, the employee's performance will also be low.

d) If the higher the level of discipline, the more improved employee performance and conversely the lower the level of discipline, employee performance will also be low.

e) If high work motivation will increase employee performance and conversely the lower the work

f) If the compensation is appropriate, it will increase the work motivation of employees so that the performance of employees in the Soppeng Regency DPRD Secretariat will also increase.

g) If the level of discipline is high, employee motivation will increase so that the performance of employees at the Soppeng Regency DPRD Secretariat also increases.

\section{References :}

Adi Indrayanto Sigit W.D. Nugroho Titi Nurfitri. Influence of Work Motivation and Work. Amriany, Sari (2016). Effect of Work Discipline and Leadership on Employee Performance in the District Office of Donri-Donri, Soppeng Regency.

Amir Sohail dkk. Effect of Work Motivation and Organizational Commitment on Job Satisfaction: (A Case of Education Industry in Pakistan). Global Journal of Management and 
Business Research: A Administration and Management, Volume 14 Issue 6 Version 1.0 Year 2014.

Ata Ghalem dkk. (2016) Performance: A concept to define! https://www.researchgate.net/publication/316630175.

B.C.M. Patnaik \& Prabir Chandra Padhi. Compensation Management: A Theoretical Preview. TRANS Asian Journal of Marketing \& Management Research (TAJMMR), Vol.1 Issue 1, September 2012.

Dalia Mohammad Soliman. Compensation Systems and Their Effects on Employees' Satisfaction at Tour Operators in Egypt. World Journal of Tourism, Leisure and Sports, Vol. 3, No. 2 (2009) 30-37.

Environment on Competitive Advantage: Study of Indonesia and China Tourism Workers. Journal of Applied Management (JAM) Volume 16 Number 1, March 2018.

Esther Patricia Paoki dkk. The Effect of Work Discipline And Team Work on Employee Performance (Case Study at PT. Bahasa Technology Solutions). Jurnal EMBA, Vol.5 No.2 Juni 2017, Hal.2385-2393.

Ghozali, Imam. (2000). Application of Multivariate Analysis with SSPSS Program (4th ed.). Semarang: Undip-Issuing Agency.

Ghozali, Imam. (2011). "Multivariate Analysis Application with SPSS Program". Semarang: Diponegoro University Publisher Agency.

Kerlinger. (2006). Behavior Research Principles. Issue 3, Printing 7. Yogyakarta: Gadjah Mada University Press.

Jon R. Katzenbach and Douglas K. Smith. https://hbr.org/1993/03/the-discipline-of-teams-2. (https://sph.uth.edu/content/uploads/2012/01/Competencies-and-Learning-Objectives.pdf)

Nasser Salim Alghanabousi dkk. The Power of Developmental Performance Appraisal. Alghanabousi NS, A. Ghani MF, Elham F. (2013). The Power of Developmental Performance Appraisal. Journal of Education and Learning. Vol.7 (1) pp. 1-10.

NN Mariana. (2018). The Effect of Competence, Compensation and Motivation on Employee Performance in the Public Works and Spatial Planning Office in Bantaeng Regency 5(2),hlm.58.

Raharjo, Sahid. (2014). How to Test Descriptive Statistics with SPSS Software Yogyakarta: Gadjah Mada University Press.

Rivai Veithzal and Jauvani Sagala. (2003). Human Resource Management for Companies. Jakarta. PT RajaGrafindo Persada

Trevor, J. Can Compensation be Strategic? A Review of Compensation Management Practice in Leading Multinational Firms. Cambridge Judge Business School, 2008.

Tiiu Kamdron. Work Motivation: Relationships with Job Satisfaction, Locus of Control and Motivation

Orientation. https://www.researchgate.net/publication/305072649_Work_Motivation_Relations hips_with_Job_Satisfaction_Locus_of_Control_and_Motivation_Orientation

William, Moch. Geri. Pengaruh Work Motivation terhadap Job Satisfaction melalui Organizational Culture. Yos Soedarso Economics Journal, Volume 2 Nomor 2, Agustus 2020. 